\title{
10 YEARS EROSION-SEDIMENTATION MONITORING: SYSTEM BASED AUTOMATIC INTERPRETATION IN COASTAL AREA OF BREBES REGENCY, CENTRAL JAVA PROVINCE, INDONESIA
}

\author{
Muhammad DIMYATI ${ }^{1}$ (D), Edy TRIHATMOKO ${ }^{2}$ (D), Muh Aris MARFAI ${ }^{3 *}$ (D)
}

DOI: $10.21163 /$ GT_2021.161.03

\begin{abstract}
:
Nowadays, coastal dynamics are mostly viewed in relation to erosion-sedimentation process. It is important to monitor the erosion-sedimentation in the coastal area in order to reduce its negative impact. This paper aims to identify the erosion-sedimentation process in the coastal area of Brebes Regency, Indonesia, using the automatic interpretation of a geographic information system (GIS) for ten years of analysis. Brebes Regency was chosen as the research area due to its high intensity of sedimentation occurrence. It is also traversed by the Jalan Pantai Utara as the most heavily used road in Indonesia. The automatic interpretation is demonstrated through the utilization of band ratio and the Digital Shoreline Analysis System (DSAS). Neither this type of analysis nor the study area in question has ever been examined before. As novelty, the result shows that sedimentation occurrences of up to $3.9 \mathrm{~km}$ were recorded in the most significant case in 2007-2016. This sedimentation is obviously as accumulation of the sediment load and sediment material, at least during last ten years. The total length of the shoreline change is the initial research in history, which precisely measures the shoreline change in Brebes Coastal Area. This research result is considered as a valuable data in coastal management for local authority, especially to handle the problem on coastal erosion and to identify the appropriate location for mitigation action due to erosion process.
\end{abstract}

Key-words: Band ratio, Coastal dynamics, erosion-sedimentation process, GIS, Brebes Indonesia.

\section{INTRODUCTION}

The surface of the Earth features three main systems, i.e. land, atmosphere, and ocean. These three systems directly influence coastal areas (Davidson and Arnott 2010), thus making coastal areas the most dynamic areas on the Earth surface (Marfai et al. 2008; Bush and Young 2009, in Young and Norby 2009; Davidson and Arnott 2010; Marfai et al. 2018; Marfai et al. 2019). Brahzt (1972, in Supriharyono 2000) defined a coastal area as one that stretches from the breakwater zone toward the land to the farthest coastal aspect measured. Based on this definition, a coastal area is directly exposed to the threat of complex natural hazards, including storms, waves, tsunamis, and tides (Obert et al. 2017). The complexity of coastal dynamics makes them an important area for study in an effort to maintain the function of the coastal area in terms of both its ecological functions and in order to better anticipate the threat of natural disasters (Marfai, et al. 2007; Marfai and King 2008a; Cozzoli et al. 2017). The complexity of the threats in coastal areas is closely related to the intensive geomorphic dynamics that characterize such areas, with two main processes at play, namely erosion and sedimentation (Marfai 2011; Mutaqin et al. 2013).

Coastal areas are characterized by their complex geomorphological dynamics (Marfai 2011; Obert et al. 2017). This complexity increases linearly with shallow water conditions and sloping coastal areas in terms of energy modification (Bird 2008). Sedimentation, as one of the main processes of geomorphological dynamics (Marfai 2011; Mutaqin et al. 2013; Dewi et al. 2016), occurs more intensely in shallow water environments. This is due to the weakening of wave and current energy as

\footnotetext{
${ }^{1}$ Department of Geography, Faculty of Mathematics and Natural Sciences, University of Indonesia, Pondok Cina, Beji, Pd. Cina, Beji, Depok, West Java, Indonesia 16424, muh.dimyati@ ristekbrin.go.id;

${ }^{2}$ Department of Geography, Faculty of Social Science, Universitas Negeri Semarang, 50229, Semarang, Indonesia, edytrihatmoko@mail.unnes.ac.id;

${ }^{3}$ Department of Environmental Geography, Faculty of Geography, Universitas Gadjah Mada, 55281, Yogyakarta, Indonesia, arismarfai@gmail.com, corresponding author.
} 
it approaches the shore, which in turn means that the terrestrial process will be stronger in the nearshore zone. With erosion and sedimentation as the main processes within coastal areas, they also reflect their dynamics (Ritter, et al. 1995; Marfai 2011). Coastal dynamics are aggravated by intensive human activities, e.g., transportation, construction activities, and other land modifications (Morton 2003; Sakijege et al. 2014). There are some GIS techniques for shoreline change monitoring, such as using GIS histogram analysis (Marfai et al. 2008; Aedla et al. 2015), or using masking operation (Randazzo et al., 2020). In the development of the mathematical models nowadays is also applied on the shoreline monitoring such as beach nourishment as part of the strategy to mitigate the erosion (Parkinson and Ogurcak 2018). By using adequate GIS Technique monitoring, the stakeholders can evaluate and take the proper action for handling erosion-sedimentation in precise and detailed measurements so that the miss-implementation of the shoreline protection will no longer occur. The miss-implementation is always followed by environmental degradation and lost, whether inside or outside the location. The environmental degradation as a result of the miss-implementation shoreline protection as reported by Jakobsen et al. (2007).

The GIS computerized methods using vector and raster format is nowadays have been implementing in various fields, including environmental monitoring for avoiding the degradation (Huang and Wu 2010; Shrestha et al. 2016), disaster mitigation (Marfai 2004; Sakijege et al. 2014), spatial planning (Marfai 2007; Buser and Farthing 2011), and many more. In the area of erosionsedimentation assessment, some reports such as by (Van and Binh 2009; Dewi et al. 2015; Dewi 2018) explained the function and advantages of GIS operation to support the spatial analysis on the erosionsedimentation study. DSAS is one of the prominent approaches to do the analysis of erosionsedimentation, especially take into account the role of the catchment area or behavior of the river. In Asia (Zhao et al. 2011; Thinh and Hens, 2017) are using DSAS to do the erosion and sedimentation analysis, especially along the coastline. In addition, DSAS is also use widely in Indonesia for example by Mutaqin (2017) and Dewi (2018), especially dealing with the coastal management.

The northern part of Central Java Province is a coastal area with sloping coastal conditions (Marfai 2012) and shallow water up to the nearshore zone (Department of Marine and Fisheries of Central Java Province 2016). This combination of existing characteristics suggests that special attention must be paid by the government of Central Java Province to managing the coastal area. Brebes Regency in the northern part of Central Java Province has a high rate of sedimentation that is influenced by its large population, commodities, and tourism (Trihatmoko 2017; Central Bureau of Statistic (CBS) of Central Java Province 2016). Establishing Brebes Regency as an area affected by a significant level of sedimentation will help to support the management of planning in preventing loss attributable to coastal dynamics, particularly in the context of sedimentation occurrences.

Sedimentation monitoring can be divided into two types, namely the terrestrial method (Lagomasino, Corbett, and Walsh, 2013) and computerized methods (Marfai et al., 2016). This study was conducted to identify and monitor the erosion-sedimentation process in Brebes Regency by modeling the occurrence of sedimentation and automatically calculating the length of the sedimentation occurrence in 10 years' analysis. This research was conducted as the first erosionsedimentation monitoring in Brebes that never been done before. The method utilized a geographic information system (GIS): DSAS, as a software extension of ArcGIS. Analysis of sedimentation using the automated ArcGIS tool, namely DSAS, or any other GIS method, has never before been conducted in Brebes Regency; therefore, this study is the first research into sedimentation using the automated ArcGIS tool in Brebes Regency. However, As a preliminary stage on this project, our work did not cover the sedimentation analysis. Since sedimentation processes need a wide study from the transport process ended up to the complex structure of sedimentary rock, it would be considered for the next stage of the project.

\section{STUDY AREA AND DATA}

According to data from the CBS of Central Java Province, Brebes Regency had the largest population in 2015 among the coastal regencies in the northern part of Central Java Province. 


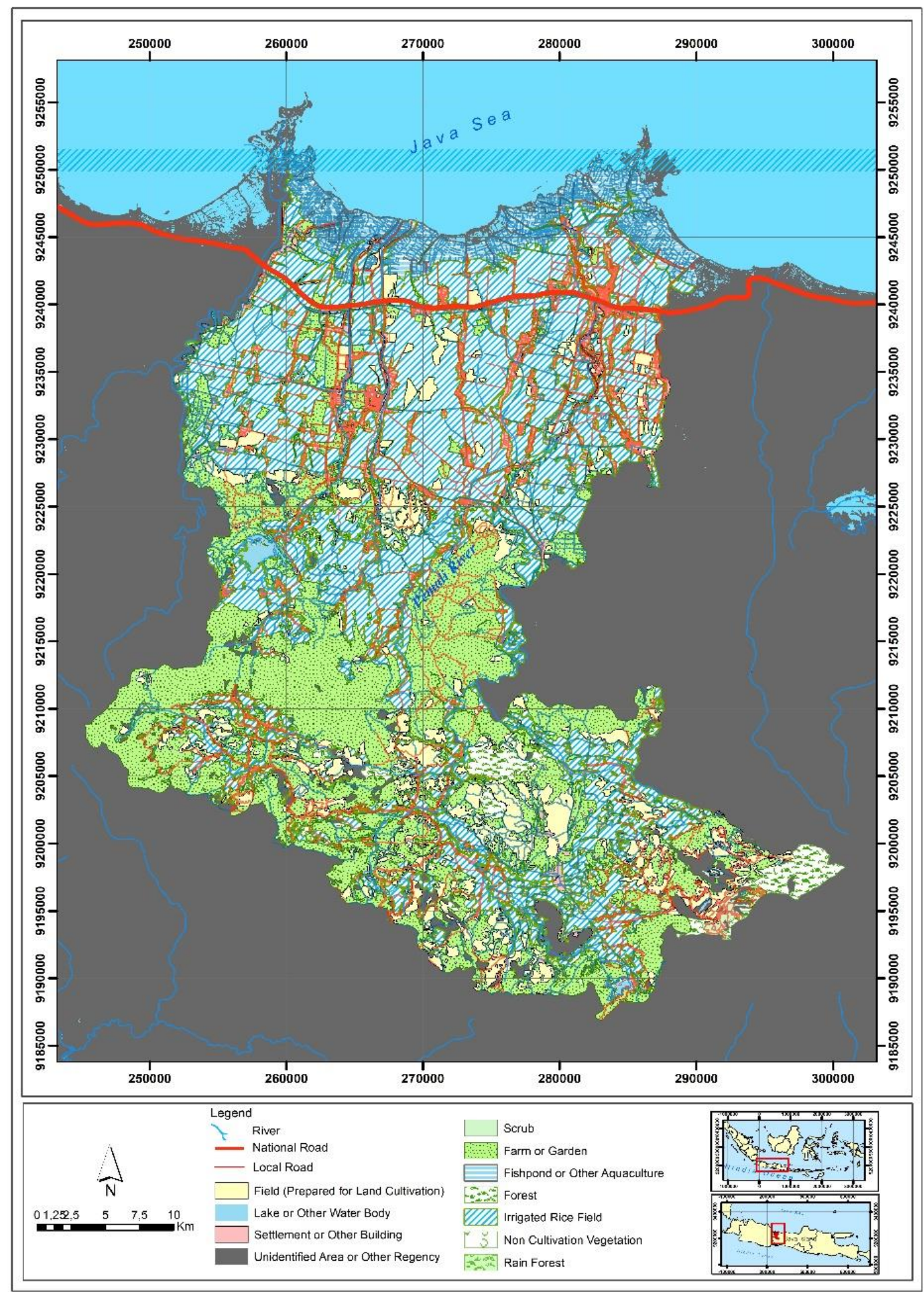

Fig. 1. The land use of Brebes Regency. The image shows that Brebes Regency is dominated by cultivated land. (Source: Geospatial Information Agency of Indonesia, 2016 and modification). 
As a regency, it has a population density of 1,075 inhabitants $/ \mathrm{km} 2$. Based on other data from CBS (2016), Brebes Regency, with its wide fish pond areas, has the highest level of fish production in Central Java Province. Cultivation from fish ponds accounted for $69,853.18$ tons, with a total of 4,021 households employed as pond farmers in 2015. The combination of this concentration of fish pond farmers and the high rate of cultivation from fish pond production shows that Brebes Regency has good fish pond potential. According to the Medium-Term Development Plan (MTBP) of Brebes Regency for the period 2017-2022, the area also has good tourism potential. This is shown by the number of visitors to the area compared to other regencies in Central Java Province. Based on tourism data, the most visited site is Randusanga Beach, which recorded 62,582 people in 2015. Such high visitor numbers also have an impact on the total amount of revenue earned from tourism, which was recorded at Rp 494,765,000 in 2015, or equal to USD 37,107.38 (Regional Planning and Development Agency 2016). Tourism in the Brebes coastal area also benefits from mangrove forest tourism. In fact, the mangrove forest has a function not only in supporting tourism, but it also plays an important role in the development of other socioeconomic sectors, including natural resources (Sukarna and Syahid 2015). The report and evaluation from the Pantura rehabilitation of Central Java Province (Fadhilah 2015) highlights the potential of the mangrove forest in the coastal area of the northern part of Central Java Province. Brebes Regency is the second largest mangrove area in the northern part of Central Java Province, with mangrove covering an area of 1,179.02 hectares, while Demak Regency has mangrove covering 2,176.79 hectares (Fadhilah 2015). Fig. 1 shows the land use of Brebes Regency.

Geomorphologically, Brebes Regency comprises folded geological structures. These structures account for the flat coastal area dominated by small grain materials as an alluvium material (Marfai 2012), which are conditions that are prone to accelerate coastal dynamics (Bird 2008). The coastal dynamic is also worsened considering that Brebes coastal area has an enclosed gulf with big headlands on both sides (Komar, 1976; Bishop, 1984; Coastal Engineering Research Center (CERC), 1984) (Fig. 1).

\section{METHODOLOGY}

In this study conducted in Brebes Regency, the first step in monitoring activity for shoreline extraction study was to identify the sedimentation process (Retnowati et al. 2012). GIS as the computerized technology was utilized as the main process. GIS was clarified as being the best and most reliable technology available nowadays for the purpose of monitoring coastal dynamics (Marfai 2004). Table 1 contains the GIS data used in this study.

Table 1.

Detailed information on the Landsat images (All images were captured at low tide).

\begin{tabular}{|c|l|l|l|l|}
\hline Data & Acquisition Date & \multicolumn{1}{|c|}{ Acquisition Time (GMT) } & \multicolumn{1}{c|}{ Sensor } & Band \\
\hline Landsat 8 & 10 August 2016 & 02.54 & OLI-TIRS & $5 / 2$ \\
\hline Landsat 5 & 2 August 2007 & 02.47 & TM & $4 / 1$ \\
\hline
\end{tabular}

The GIS data used in the study were obtained from The United States Geological Survey (USGS). Landsat 8 and 5 were chosen since these two images are in the good condition and appropriate to be used for spatial analysis and further image processing in the time span of 2007-2018. Landsat 8 was published on February 2013, and Landsat 5 had been decommissioned on June 2013. Band 5 and band 2 in Landsat 8 were appropriate band to do analysis related to water and land, such as in the coastal environment. Band 5 as the near infrared band has the wave length up to $0.85-0.88 \mu \mathrm{m}$ on the $30 \mathrm{~m}$ of spatial resolution. This band is stressing on the biomass content and shoreline. By having a near infrared band, the analysis is easier considering that the wave length is optimally absorbed by the water body, and band 2 is the blue band with emphasizing on bathymetric and soil. By this band combination, distinguishing the land and waterbody will much easier. In the same characteristics, band 4 and band 1 in Landsat 5 are also as the near infrared and blue band, therefore those 2 bands are also suitable to do the shoreline monitoring. Those two types of Landsat images were captured on 
the low tide condition and this is considered as the advantages of this data, while those image on the same condition and it will useful for monitoring sensitive area such as shoreline.

The GIS tool has been used to extract the Landsat-5 TM in 2007 and Landsat-8 OLI / TIRS in 2016, paths 120-121 and row 65. The time range of this analysis was classified as a fit time range variation in shoreline change analysis (Rijn 2010). Shoreline data from Landsat-8 OLI/TIRS was obtained using Band 5 and Band 2 or a near-infrared band and blue band. These were the best two combinations for reflecting the boundary of land and water (Khawfany et al. 2017). For more detail, Band 5 on Landsat 8 OLI/TIRS as a near-infrared band has a zero-reflection value for water so that a clear shoreline can be obtained. Furthermore, in terms of wavelength matching, Landsat-5 TM was conducted using Band 4 and Band 1. The band information for Landsat-5 TM and Landsat-8 OLI/TIRS was processed using ENVI (Environment for Visualizing Images) software in order to extract the early shoreline interpretation data, as shown in Fig. 2. The band ratio method was selected as the most effective means of manipulation for the pixel values (Van and Binh 2009). Manipulation refers to the use of two binary codes to represent water and land: " 1 " for land, and "0" for water. However, utilizing the binary code as typical raster data makes it much easier to complete the shoreline determination process. After obtaining the boundary line through band ratio processes using ENVI software (Fig. 2), a further process was conducted using ArcGIS software (ENVI software is designed specifically for GIS users and integrates fully with ESRI's ArcGIS software) and the DSAS tool. DSAS is a separate extension of the ArcGIS software that was created in May 2009, which means it is available only for ArcGIS 9.2 and above (Himmelstoss, 2009). The extension works using a vector data format. DSAS processing is based on the principle of determining the length or extent of the dynamic process of the existing coastal areas, whether in the form of erosion or sedimentation. Information on the length or extent of the process of the coastal dynamics in the area is obtained from the data attribute. Use of the DSAS tool enables more accurate and effective measurement of the shoreline changes as mentioned in this research. Fig. 3 illustrates the workflow of the research.

\section{RESULTS AND DISCUSSIONS}

Brebes Regency, as one of the regencies in northern Central Java Province, was identified as an area with a high impact of coastal dynamics, especially with regard to the sedimentation effect (Trihatmoko, 2017). Fig. 4 indicates that the two binary codes were produced by ENVI for the Brebes coastal area in 2016 as raster data. By eliminating the binary code representing the area of water, data for both the land and shoreline are obtained. The later result obtained using the detailed DSAS tool reveals sedimentation to be the dominant process in Brebes Regency compared to erosion. This result is shown in Fig. 5.

Zooming is carried out in several parts with significant and clear changes, i.e., on boxes a, b, c, $\mathrm{d}$, and e in Fig 5. In locations marked with the box a, erosion is clearly visible compared to sedimentation, this will certainly bring disadvantages to most of the coastal land in part a, especially agricultural land and residential areas. Meanwhile, box b tends to increase sedimentation. This sedimentation is expected to come from the river above it. Box $\mathrm{c}$ is also following the condition in the area of box b. In this area, vegetation protection with mangroves is starting to develop. The existence of the barrier islands in front of box c also contributes to reducing the energy of the sea as the main energy for triggering erosion. So, the sediment that is brought by the stream can spread along the shore. The shape of the delta also verifies it as the main outlet of the Pemali River. The shape is classified as the lobate. That means the stream energy is dominated compare to sea energy. It is also confirmed by the main sedimentation process in the area of box $\mathrm{d}$. This location has been found as the most significant sediment processes compare to other locations, followed by the area of box e. The sedimentation process lead to delta development are appear in the boxes a, b, c, d, and e, we could assume that the sediments transfer from those river plays important role on the development of the sediment formation on the coastal area. Further observation and grand size as well as sediment measurement on rivers are needed in order to get more understanding on the significant contribution of river sediments on the development of the coastal sedimentation process and formation. 


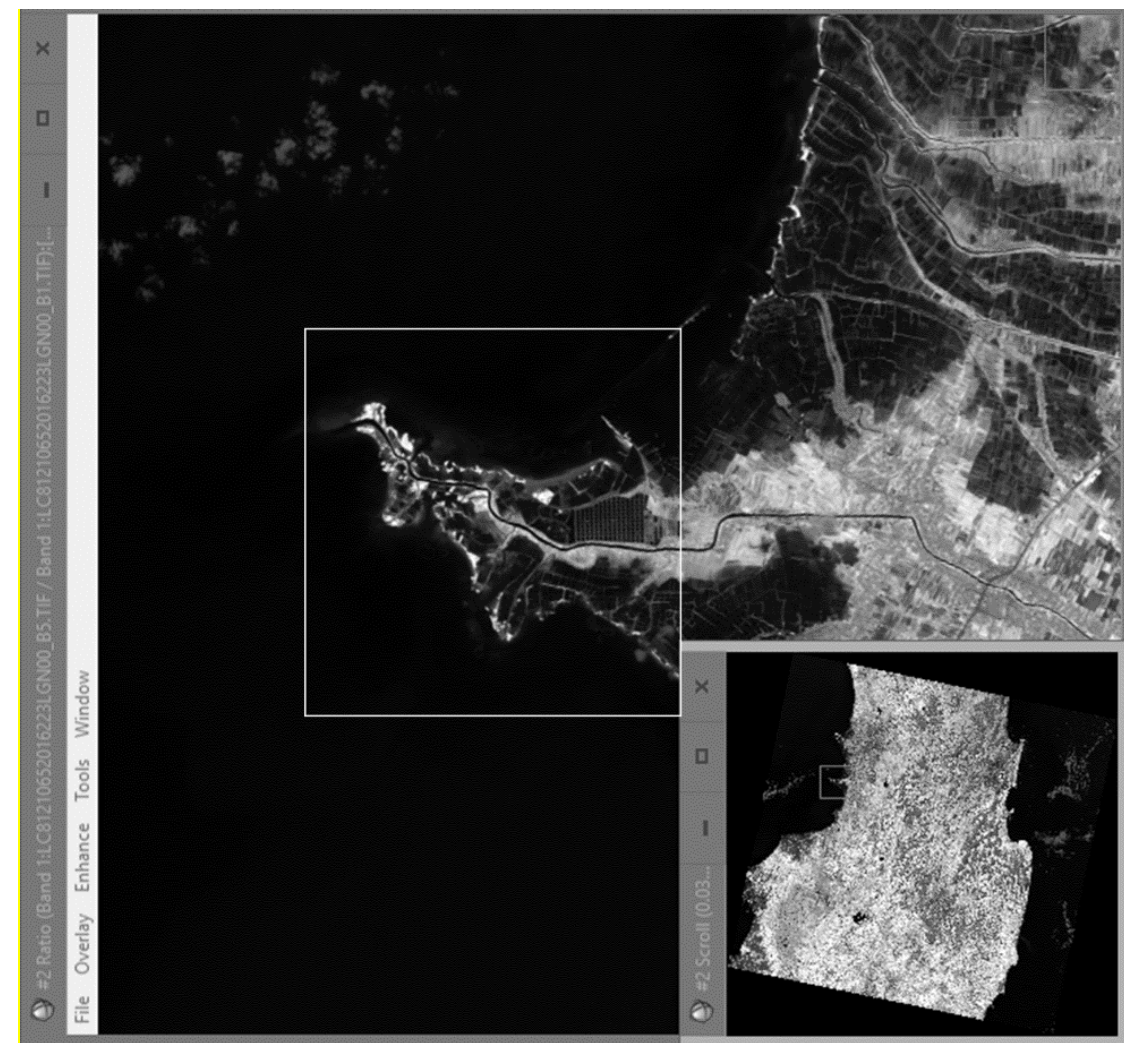

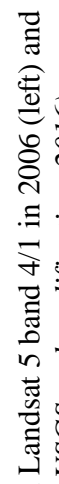

s.

.

는

2

芯

든

这

4 동

范

乞

트

s

38

ㅍ

흐

足

चี

을

크

츨

可

일

皮

\&

อ స

ญ्.

홍

อ.

(ब)

苂 \&

可

过

仓

Ð

흥

ฐ $\Xi$

응

อิ

퉐 몽

익

ㄱ

ำ 


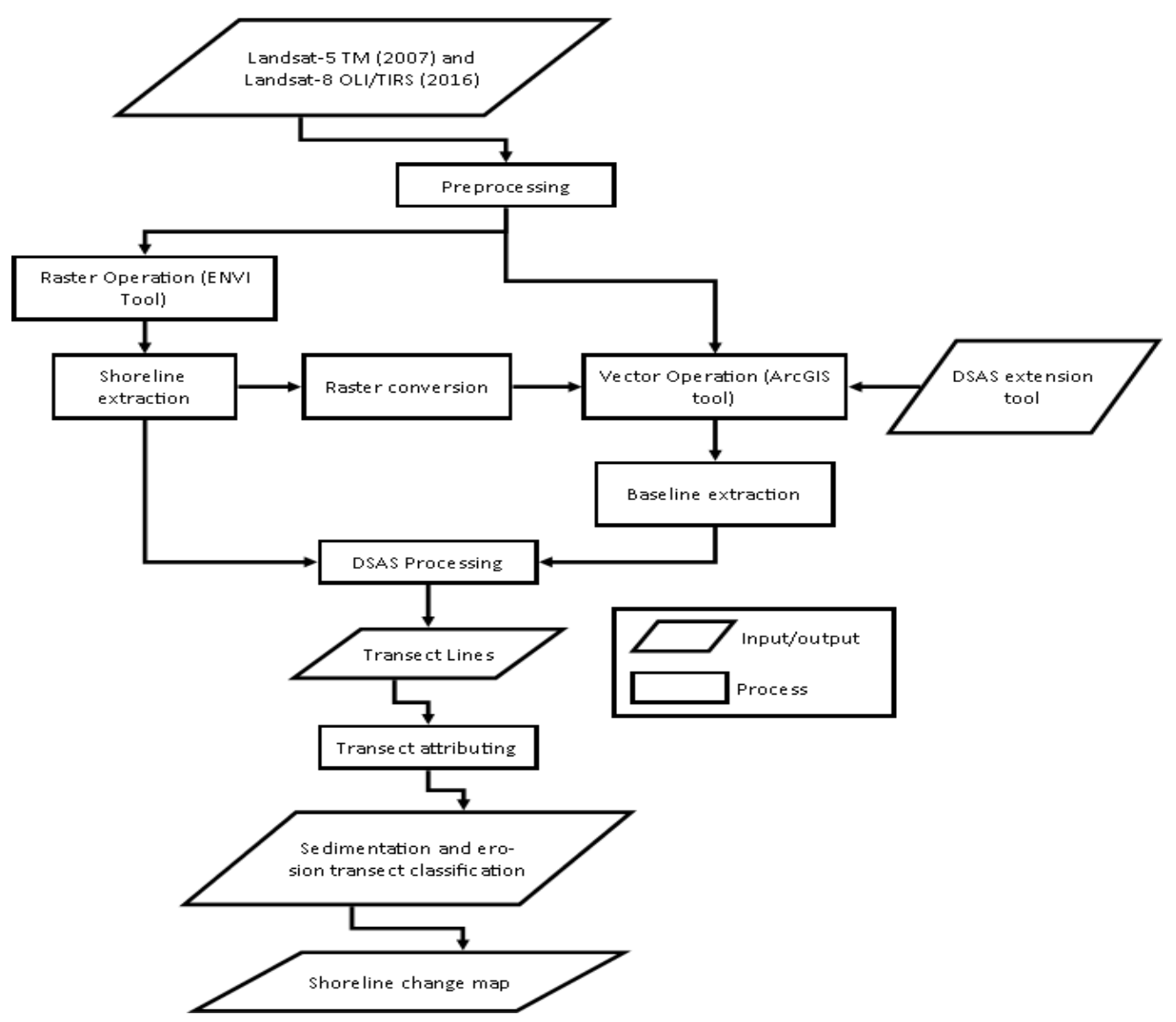

Fig. 3. Research workflow.

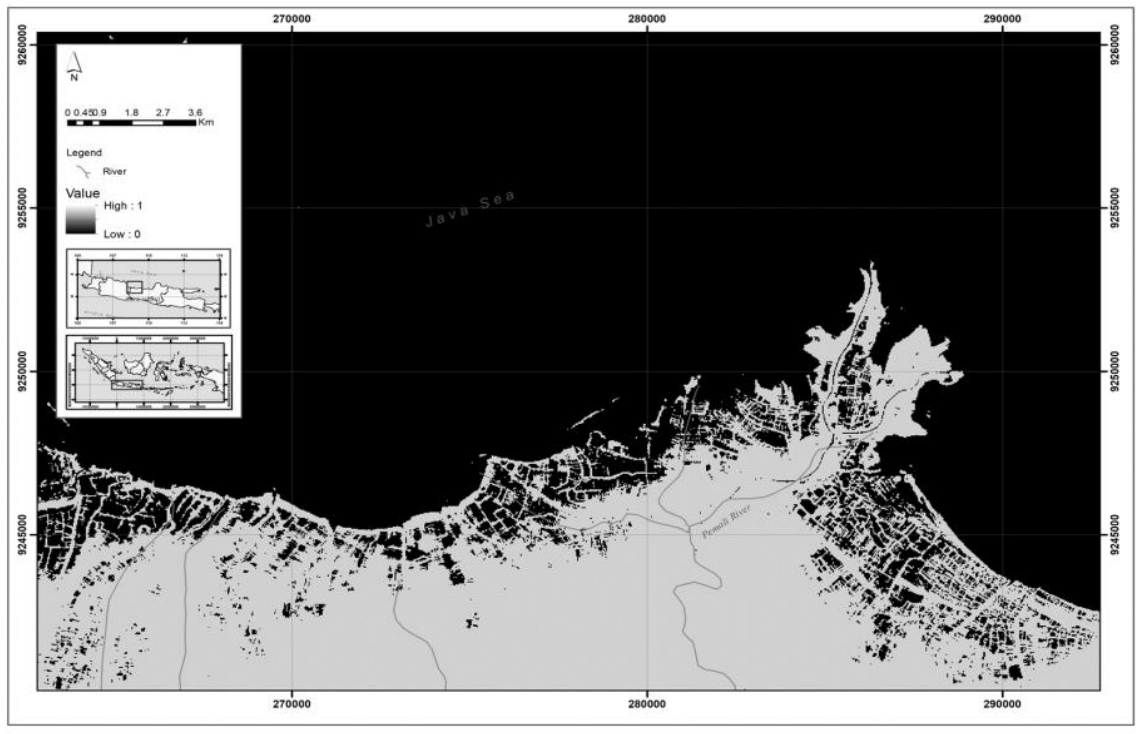

Fig. 4. Map of land and water separation of Brebes coastal area in 2016 using ENVI. 

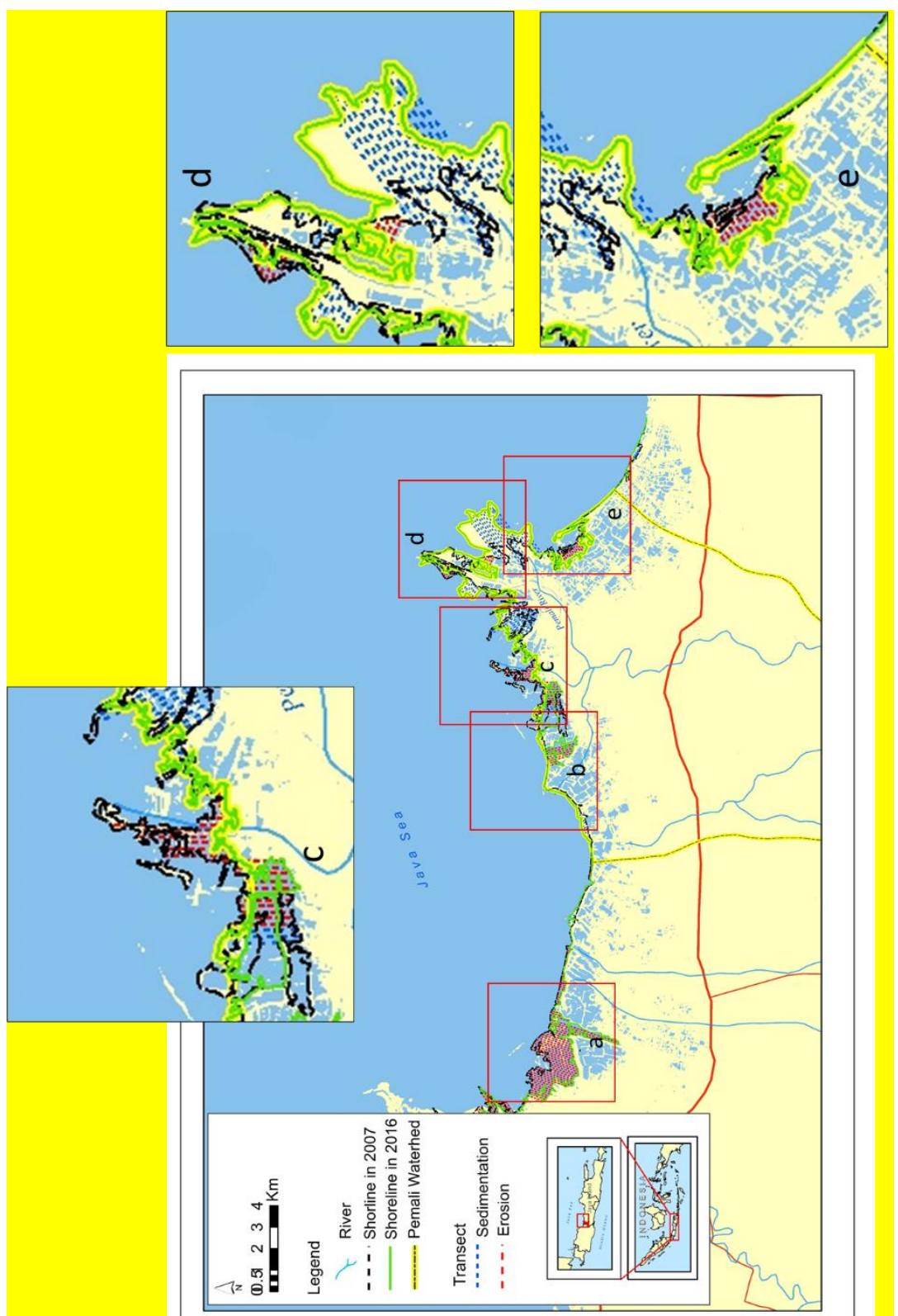

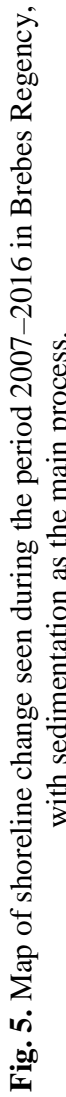
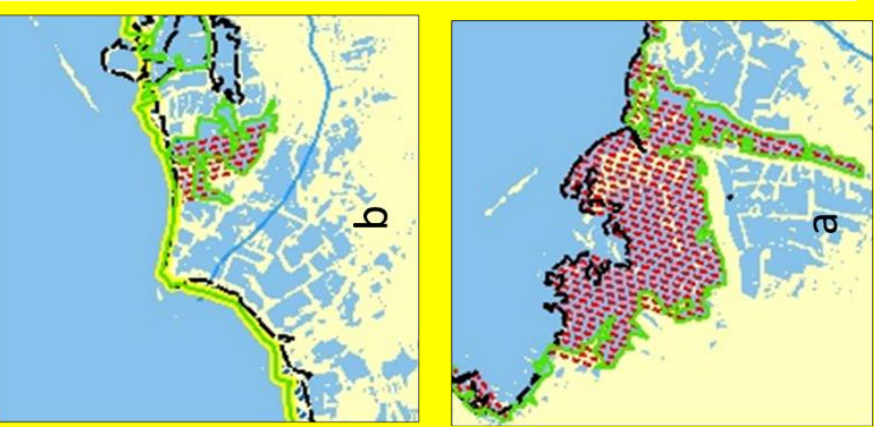
The maximum extent of the sedimentation occurrence was automatically marked using the DSAS method. This gave rise to a particular concern since the existing line of change is based on a point facing open water or sea without any borders; however, it did not always originate from a point on the shoreline but could lead to a curve in a river that when traced to the sea was not blocked by land as a separator. The maximum length of the sedimentation occurrence in this research was found to be $3.9 \mathrm{~km}$ over the 10-year period in question. This length of the sedimentation occurrence captured exceeded that of the erosion, which was measured at up to $3.3 \mathrm{~km}$. This data, as obtained from the data attribute in DSAS processing, is shown in Fig. 6. Trihatmoko (2017) obtained a measurement of $2.26 \mathrm{~km}$ for the maximum shoreline change in the same location. The different result is possible might be due to the different methods were applied. In this research, DSAS is used while Trihatmoko (2017) utilized histogram analysis on the shoreline detection procedure using raster GIS format. The resolution in raster environment may cause the different resolution in result.

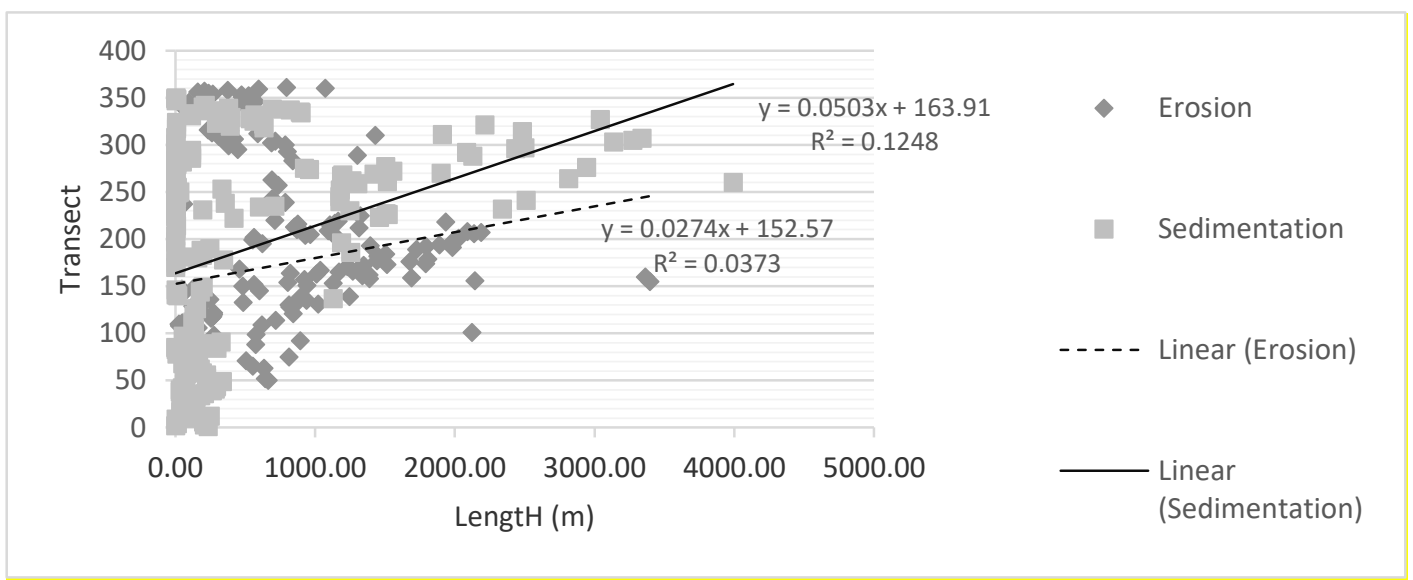

Fig. 6. Graph of erosion and sedimentation occurrences in Brebes coastal area in 2007-2016 using $100 \mathrm{~m}$ distance of transect (361 transect multiplied by $100 \mathrm{~m}$ equal to $36.1 \mathrm{~km}$ ).

Fig. 6 shows the trend of erosion-sedimentation occurrences. A more detailed trend analysis can be defined as an attempt to see the movement of an upward or downward trend in the long term which is obtained from the average change over time. An increasing trend is called a positive trend and a downward trend is called a negative trend. The trend can be formulated using a linear function equation. A positive and negative trend can be written, respectively:

$$
\begin{aligned}
& Y=a x+b \\
& Y=-a x+b
\end{aligned}
$$

$Y$ is the dependent variable, while $a$ is the direction coefficient, $b$ is a constant which is the intersection point on the y-axis, and $X$ is the independent variable. The two linear equations shown in Fig. 6 can be analyzed that each of them has a positive trend. It means that there is an increase in both processes. However, the $b$ value for sedimentation ca. of 163.91 while for erosion the value is 152.57 . Thus, that sedimentation processes are more dominant than erosion. The trend analysis also shows the coefficient of determination $R^{2}$. The value of $\mathrm{R}^{2}$ is defined as the contribution of the influence given by $X$ to $Y$. In other words, the value of $\mathrm{R}^{2}$ is useful for predicting and seeing the magnitude of the contribution of influence given by $X$ variable simultaneously to $Y$ variable. The value of $R^{2}$ generally ca. 0-1. If it shows a negative value, it can be determined that there is inverse influence of $X$ variable on $\mathrm{Y}$ variable. Furthermore, the smaller value of $\mathrm{R}^{2}$ indicates that the effect of $\mathrm{X}$ variable on $\mathrm{Y}$ variable is getting weaker. On the other hand, if the $\mathrm{R}^{2}$ value gets closer to 1 , then this influence is getting stronger. In the graph shown in Fig. 6, the $\mathrm{R}^{2}$ value for sedimentation is greater than for erosion, although both tend to be small ca. 0.1248 and 0.0373 , respectively. However, the $\mathrm{R}^{2}$ value in 
sedimentation means that the closer the transect approaches the estuary, there is a linear relationship with the increase in sedimentation length, since the transect was measured along the shore heading to the east or river mouth of the Pemali River.

The occurrence of sedimentation up to $3.9 \mathrm{~km}$ was the result of terrestrial material transported by the river system. It shows that the existing sedimentation linearly follows the flow pattern of the river, which means the deposition originally derived from the mainland. This finding is potentially significant as it contradicts the theory that a build-up of sedimentation in coastal areas results from erosion in other coastal areas (Pethick 1984). Sedimentation processes are indeed controlled by several energies, whether form the inland such as river energy or from the sea such as wave and current energies. In this case, wave characteristics in the study area is considered calm and only sometime a bit strong wave occurs. Domination of the sediment supply from the river are very obvious, as it is indicated in several parts of the shore with the delta developments. However, further research is needed to observe, measure and quantify the sediment supply from the rivers as well as to measure the tide and wave energies. It can be concluded that coastal and watershed management should be integrated (Marfai and King 2008b). This type of integrated management demands the targeted involvement of many aspects and sectors related to both watershed and coastal areas (Buser and Farthing 2011).

As measured, sedimentation in the nearshore zone occurs in the Pemali River mouth (shown in Fig. 5), or as riverine sediments (Kao et al. 2008). Guided by data from the Geospatial Information Bureau (GIB), the Pemali Watershed is the widest of the ten watersheds in Brebes Regency. This means that the measurement results obtained using DSAS show a direct correlation with the watershed-wide situation. The main land use in the Pemali Watershed was identified as farm or garden, accounting for up to $35.26 \%$, as shown in Table 2. This finding demonstrates that farming activities in Pemali Watershed are the main activity of the community and make a major contribution to sedimentation occurrence. It also reveals that the anomaly in the form of Jalan Pantai Utara has no impact on the urban activities, as is the case in other areas through which it traverses (Marfai et al. 2017). Surface material is transferred to the river system via overland flow as a result of continuous tillage activity (Arsyad 2010). These findings thus reveal that farm and garden activities are the two main activities that trigger sedimentation processes arising from soil erosion. The dynamic of the land cultivation in a farm and garden contribute to the sediment load and material brought to the river. In a certain period of time it would also contribute to the river convection.

Pemali Watershed Characteristics.

Table 2.

\begin{tabular}{|c|c|c|}
\hline Land use & Area (ha) & Percent \\
\hline Lake & 67.91 & 0.05 \\
\hline Pond & $2,813.50$ & 2.13 \\
\hline Building & 9.38 & 0.01 \\
\hline Mangrove & 21.28 & 0.02 \\
\hline Wood & $3,472.24$ & 2.63 \\
\hline Grassland & 439.92 & 0.33 \\
\hline Farm/garden & $46,573.51$ & 35.26 \\
\hline Settlement & $10,360.25$ & 7.84 \\
\hline Rice field & $30,474.72$ & 23.07 \\
\hline Rain-fed field & $15,030.19$ & 11.38 \\
\hline Moor & $14,349.97$ & 10.86 \\
\hline Non-cultivated vegetation & 47.12 & 0.04 \\
\hline Unidentified landuse & $8,423.32$ & 6.38 \\
\hline Total & 132,083.32 & 100.00 \\
\hline
\end{tabular}

Information: $\mathrm{W}$ stands for watershed

Source: BIG, 2017 (information: W refers to watershed) 
The results displayed in Fig. 5 show the location of the dominant occurrence of sedimentation in Brebes Regency, precisely in Brebes District. This sedimentation has an adverse impact in terms of making the estuary shallow and difficult for fishermen to either anchor or sail. The sedimentation is potentially harmful as accumulations are potentially toxic due to the previously mentioned farming activities that may employ chemical fertiliziers and are detrimental to the environment, such as by reducing fish catches and compelling fishermen to travel greater distances (Fleischer, Orsi and Richardson 2001).

In addition, evaluating accuracy of the GIS-model is necessary to be done in order to ensure the quality of the developed model. In this project ground checking has been done in 2016 and 2017 on the study area, particularly on the spot of erosion and sedimentation, to confirmed the model result. There are three important spots have been confirmed using ground checking and all the areas confirmed the model results. The ground checking was focused on the location limited on box b, c, d, and e (Fig. 6) since the trend analysis was confirmed intensively occurred when the transect getting closer to the river mouth of the Pemali River. Four observed areas are shown in Fig. 7 with their coordinates. This ground checking is a common method but considered as an appropriate validation procedure. However, advanced validation process for more detail model could be considered and could be proposed for the next agenda of research.
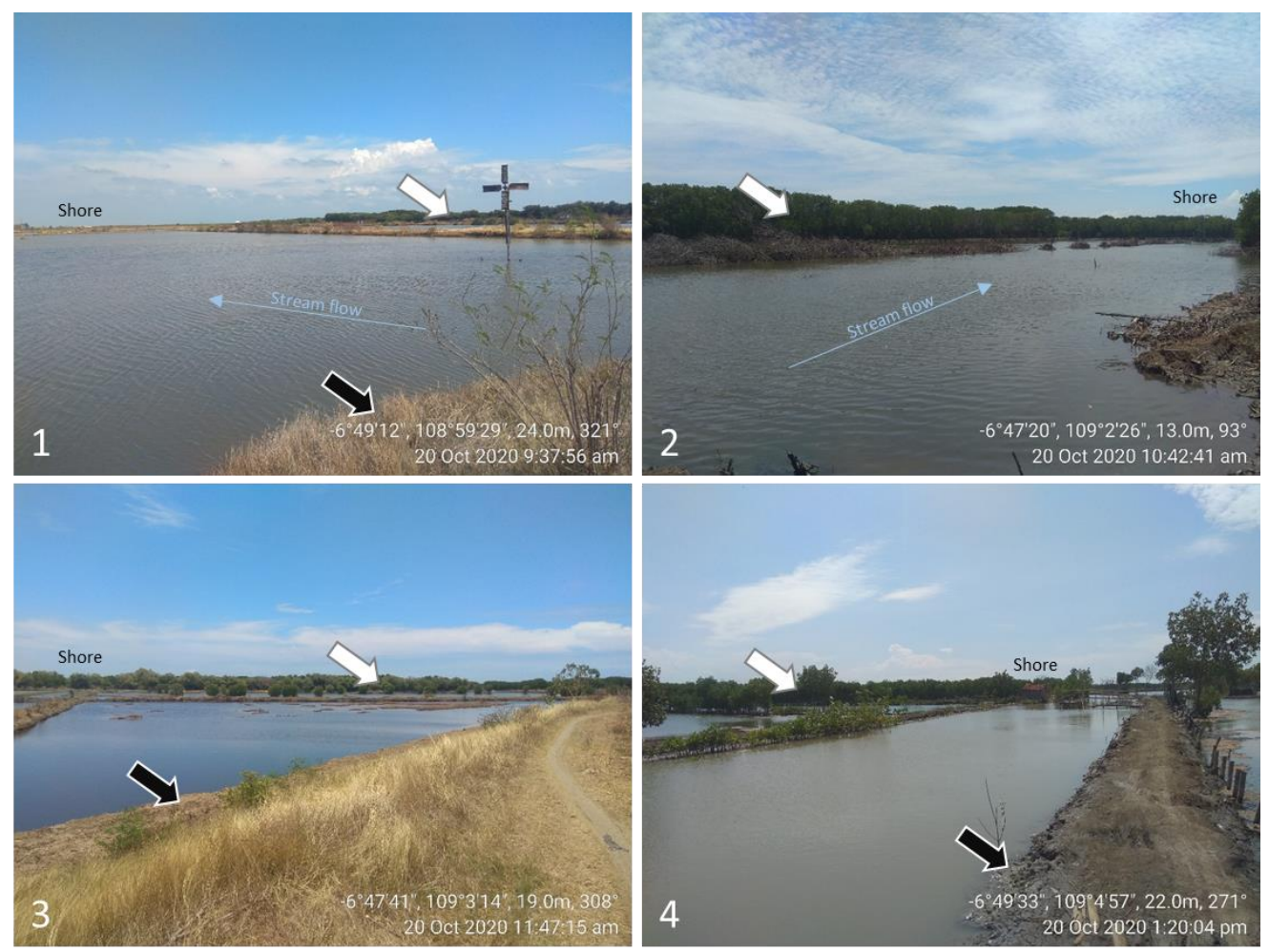

Fig. 7. Location 1, 2, 3, and 4 are respectively show the area of box b, c, d, and 3 in Fig. 5. All of the areas are dominated by the process of sedimentation, it is confirmed by the mangrove development in these areas (white arrows). The land and fish ponds are also well developed (white arrows), furthermore people have tried to build new dykes for the fish pond that is showed in location 4 , it shows that people may realize that the location is stable. 


\section{CONCLUSIONS}

Bands 4 and 1 of Landsat- 5 TM were used to extract the ratio information between land and water bodies, while Landsat- 8 OLI/TIRS used Bands 5 and 1 . This non-conformity was used to adjust the different wavelengths of the two Landsats. Even if the result shown by DSAS is completely automatic, the line of change was based on a point facing open water or sea without any borders, although it does not always originate from a point on the shoreline but can lead to a curve in a river that when traced to the sea is not blocked by land as a separator. Sedimentation was found to be the dominant process as opposed to erosion, with a maximum sedimentation length of $3.9 \mathrm{~km}$ recorded, as triggered by farming activities in the Pemali Watershed. The direct impact of the sedimentary occurrence on the community centered on the reduced ability to anchor or sail.

Both erosion and sedimentation on the coastal area are the most important issue for coastal manager and community. Erosion triggers the environmental problem lead to the loss of land for agriculture, and thread the coastal settlement. In other hands, additional coastal land appears due to the sedimentation process. The coastal manager should aware with this situation, since it might be possible that social conflict occurs due to this "new" land development. Therefore, this research result could contribute to the local authority in the form of spatial data for the decision-making process. A recommendation is thus proposed to conduct an integrated study related to the amalgamation of watershed and coastal management since the river served as the main source of sediment.

\section{Acknowledment}

High appreciation and special thanks to Sunarto for the constructive advice on this work. We also thank to Medina Uli Alba Somala and Isbakhul Lail for the field survey.

\section{R E F E R E N C E S}

Aedla, R., Dwarakish, G. S., \& Reddy, D. V. (2015) Automatic Shoreline Detection and Change Detection Analysis of Netravati-GurpurRivermouth Using Histogram Equalization and Adaptive Thresholding Techniques. Aquatic Procedia, 4, 563-570.

Arsyad, S. (2010) Land and Water Conservation Second Ed. (in Bahasa: Konservasi Tanah dan Air Edisi Kedua). IPB Press, Bandung.

Bird, E. (2008) Coastal Geomorphology an Introduction Second Edition. University of Melbourne, Melbourne.

Buser, M. \& Farthing, S. (2011) Spatial Planning as an Integrative Mechanism: A Study of Sub-Regional Planning in South Hampshire, England. Planning Practice and Research, 26 (3), 307-324.

Center Bureau of Statistic. (2016) Province of Central Java Province in Number, 2016 (in Bahasa: Provinsi Jawa Tengah dalam Angka Tahun 2016). Statistic Center Bureau, Central Java Province.

Cozzoli, F., Smolders, S., Eelkema, M., Ysebaert, T., Escaravage, V., Temmerman, S., Meire, P., Herman, P. M. J. \& Bouma, T. J. (2017) A Modeling Approach to Assess Coastal Management Effects on Benthic Habitat Quality: A Case Study on Coastal Defense and Navigability. Estuarine, Coastal and Shelf Science, 184, 6782.

Davidson, R. \& Arnott (2010) Introduction to Coastal Processes and Geomorphology. Cambridge University Press, London.

Dewi, R. S. (2018) Monitoring Long-term Shoreline Changes Along the Coast of Semarang. IOP Conf. Series: Earth and Environmental Science, 284 (2019) 012035.

Dewi, R. S., Bijker, W., Stein, A. \& Marfai, M. A. (2016) Fuzzy Classification for Shoreline Change Monitoring in a Part of the Northern Coastal Area of Java, Indonesia. Remote Sensing, 8, 1-25.

Department of Marine and Fisheries of Central Java Province (2016) Coastal Resources Study for Region Act Revision of Zonation Plan of Coastal and Small Island (RZWP3K) in the Province of Central Java Province 
(in Bahasa: Kajian Sumberdaya Pesisir dalam Rangka Revisi Perda RZWP3K Provinsi Jawa Tengah). Brief Repot. Department of Marine and Fisheries of Central Java Province, Semarang.

Fadhilah, S. M. (2015) Mangrove Ecosystem Restoration in Kendal Regency (in Bahasa: Restorasi Ekosistem Mangrove di Kabupaten Kendal). Bachelor Thesis. Faculty of Economics and Business, Diponegoro University, Semarang.

Fleischer, P., Orsi, T. H. \& Richardson, M. D. (2001) Distribution of Free Gas in Marine Sediments: A Global Overview. Geo-Marine Letters, 21, 109-122.

Geospatial Information Bureau (2017) Geospatial for Nation (in Bahasa: Geospasial untuk Negeri). http://tanahair.indonesia.go.id/portal/downloadViaZipFile. Accessed 13 January 2017.

Himmelstoss, E. A. (2009) DSAS 4.0 Installation Instructions and User Guide, in: Thieler, E. R., Himmelstoss, E. A., Zichichi, J. L. \& Ergul, A. (2009) Digital Shoreline Analysis System (DSAS) version 4.0 - An ArcGIS extension for calculating shoreline change: U.S. Geological Survey Open-File Report, 2008-1278.

Huang, M. \& Wu, Y. (2010) Environmental Monitoring System Based on GIS and Wireless Communications. Proceeding. The 4th International Conference on Bioinformatics and Biomedical Engineering.

Jakobsen, F., Hartstein, N., Frachisse, J. \& Golingi, T. (2007) Sabah Shoreline Management Plan (Borneo, Malaysia): Ecosystems and Pollution. Ocean \& Coastal Management, 50 (1), 84-102.

Kao, S. J, Jan, S., Hsu, S. C., Lee, T. Y. \& Dai, M. (2008) Sediment Budget in the Taiwan Strait with High Fluvial Sediment Inputs from Mountainous Rivers: New Observations and Synthesis. Terrestrial, Atmospheric and Oceanic Science, 19 (5), 525-546.

Khawfany, A., Aref, M. A., Matsah, M. \& Taj, R. (2017) Utilizing Landsat-8 Data in Mapping of Sabkha, Mangroves, and Land Covers in Jizan Coastal Plain, Southwestern Saudi Arabia. Arabian Journal of Geosciences, 10 (5), 102-120.

Lagomasimo, D., Corbett, D. R. \& Walsh, J. P. (2013) Influence of Wind-Driven Inundation and Coastal Geomorphology on Sedimentation in Two Microtidal Marshes, Pamlico River Estuary, NC. Estuaries and Coasts, 2013 (36), 1165-1180.

Marfai, M. A. (2004) Tidal Flood Hazard Assessment: Modeling i Raster GIS, Case in Western Part of Semarang Coastal Area. Indonesian Journal of Geography, 36 (1), 25-38.

Marfai, M. A. (2007) Coastal Dynamic and Shoreline Mapping: Multi-Sources Spatial Data Analysis in Semarang Indonesia. Environ Mont Assess, 142, 297-308.

Marfai, M. A. (2011) The Hazards of Coastal Erosion in Central Java, Indonesia: An Overview. Malaysian Journal of Society and Space, 3, 1-9.

Marfai, M. A. (2012) Preliminary Assessment of Coastal Erosion and Local Community Adaptation in Sayung Coastal Area, Central Java - Indonesia. Quaestiones Geographicae, 31 (3), 47-55.

Marfai, M. A. \& King, L. (2007) Monitoring Land Subsidence in Semarang, Indonesia. Environmental Geology, 53, 651-659.

Marfai, M. A. \& King, L. (2008a) Coastal Flood Management in Semarang, Indonesia. Environmental Geology, $55,1507-1518$.

Marfai, M. A. \& King, L. (2008b) Tidal Inundation Mapping under Enhanced Land Subsidence in Semarang, Central Java Indonesia. Natural Hazards, 44, 93-109.

Marfai, M. A., Almohammad, H., Dey, S., Susanto, B. \& King, L. (2008) Coastal Dynamic and Shoreline Mapping: Multi-Sources Spatial Data Analysis in Semarang Indonesia. Environ Monit Assess, 142, $297-$ 308.

Marfai, M. A., Trihatmoko, E., Hizbaron, D. R., Sandholz, S. \& Dimyati, M. (2017) Band Ratio Modification for Monitoring the Suspended Sediment Distribution Pattern in the Urban Coastal Area. Unpublished Manuscript.

Marfai, M. A., Tyas, D. W., Nugraha, I., Fitriatul'Ulya, A. \& Riasasi, W. (2016) The Morphodynamics of Wulan Delta and its Impacts on the Coastal Community in Wedung Subdistrict, Demak Regency, Indonesia. Journal of Environmental Protection, 2016(7), 60-71.

Marfai, M. A., Trihatmoko, E., Sunarto, Wulandari, Risanti, A. A. \& Kurniawan, I. A. (2018) Preliminary Study of Coastal Circulation Cells in the Coastal Area of Kendal, Indonesia. IOP Conf. Series: Earth and Environmental Science, 256 (2019) doi:10.1088/1755-1315/256/1/012030. 
Marfai, M. A., Trihatmoko, E., Ervita, K. \& Purnama, I. S. (2019) Granulometric Extraction Value to Determine Waves, Currents, and Tides Characteristic of Tangsi Beach (Pink Beach) East Lombok Regency, Indonesia. IOP Conf. Series: Earth and Environmental Science, 256 (2019) doi:10.1088/1755-1315/256/1/012030.

Mutaqin, B. W. (2017) Shoreline Changes Analysis in Kuwaru Coastal Area, Yogyakarta, Indonesia: An Application of the Digital Shoreline Analysis System (DSAS). International Journal of Sustainable Development and Planning, 12(7), 1203-1214.

Mutaqin, B. W., Trihatmoko, E., Ftriani, A. K. N. \& Jumari (2013) Preliminary Study of the Coastal Dynamics in Porong Delta after the Sidoarjo Mud Volcano Eruption in 2006 (in Bahasa: Studi Pendahuluan Dinamika Wilayah Kepesisiran di Muara Delta Porong setelah Erupsi Mud Volcano Sidoarjo Tahun 2006). Proceeding of Seminar Nasional Pendayagunaan Informasi Geospasial untuk Optimalisasi Otonomi Daerah 2013, Universitas Muhammadiyah Surakarta, Surakarta.

Morton, R. A. (2003) An Overview of Coastal Land Loss: With Emphasis on the Southeastern United States: U.S. Geological Survey, Open File Report, 3(337), 29.

Obert, A. I. (2017) High-Resolution Multi-Scale Modelling of Coastal Flooding due to Tides, Storm Surges and Rivers Inflows. A Cork City Example. Coastal Engineering, 121, 278-296.

Parkinsonm R. W., \& Ogurcak, D. E. (2018) Beach Nourishment is not a Sustainable Strategy to Mitigate Climate Change. Estuarine, Coastal and Shelf Science, 212, 203-209.

Randazzo, G., Barecca, G., Cascio, M., Crupi, A., Fontana, M., Gregorio, F., Lanza, S., \& Muzirafuti, A. (2020) Analysis of Very High Spatial Resolution Images for Automatic Shoreline Extraction and Satellite-Derived Bathymetry Mapping. Geosciences, 10, 172.

Regional Planning and Development Agency of Brebes Regency (2016) Technocratic Study of the Initial Draft of Medium Term Regional Development Plan (RPJMD) of Brebes Regency 2017-2022 (in Bahasa: Kajian Teknokratis Draft Rancangan Awal Rencana Pembangunan Jangka Menengah Daerah (RPJMD) Kabupaten Brebes tahun 2017-2022). Regional Planning and Development Agency of Brebes Regency, Brebes.

Retnowati, A., Marfai, M. A. \& Sumantyo, J. T. S. (2012) Rip Currents Signatures Zone Detection on ALOS PALSAR Image at Parangtritis Beach, Indonesia. Indonesian Journal of Geography, 44(1): 12-27.

Ritter, D. F., Kochel, R. C. \& Miller, Jr. (1995) Process Geomorphology. Third Edition. Wm C Brown Company Publishers, USA.

Sakijege, T., Sartohadi, J., Marfai, M. A., Kasenga, G. R. \& Kasala, S. E. (2014) Assessment of Adaptation Stategies to Flooding: A Comparative Study between Informal Settlements of Keko Machungwa in Das ed Salaam, Tanzania and Sangkrah in Surakarta, Indonesia. Jàmbá: Journal of Disaster Risk Studies, 6 (1), Art. \#131, 10 pages. http:// dx.doi.org/10.4102/jamba. v6i1.131.

Shrestha, F., Uddin, K., Maharjan, S. B., \& Bajracharya, S. R. (2016) Aplication of Remote Sensing and GIS Environmental Monitoring in the Hindu Kush Himalayan Region. Environmental Science, 3(4), 646-662.

Sukarna, R. M. \& Syahid, Y. (2015) FCD Application of Landsat for Monitoring Mangrove in Central Kalimantan. Indonesian Journal of Geography, 47 (2), 160-170.

Supriharyono. (2000) Natural Resources Preservation and Management in Tropical Coastal Area (in Bahasa: Pelestarian dan Pengelolaan Sumber Daya Alam di Wilayah Pesisir Tropis). PT Gramedia Pustaka Utama, Jakarta.

Thinh, N. A., \& Hens, L. (2017) A Digital Shoreline Analysis System (DSAS) Applied on Mangrove Shoreline Changes Along the Giao Thuy Coastal Area (Nam Dinh, Vietnam) during 2005-2014. Vietnam Journal of Earth Sciences, 39(1), 87-96.

Trihatmoko, E. (2017) Process and Impact of the Coastal Dynamics in the Central Java and Special Region of Yogyakarta (in Bahasa: Proses dan Dampak Dinamika Wilayah Kepesisiran Jawa Tengah dan Daerah Istimewa Yogyakarta). Master Thesis, Faculty of Geography Universitas Gadjah Mada, Yogyakarta.

Van, T. T., \& Binh, T. T. (2009) Application of Remote Sensing for Shoreline Change Detection in Cuu Long Estuary. VNU Journal of Science, Earth Science, 25, 217-222.

Young, R. \& Norby, L. (2009) Geological Monitoring: Boulder. Geological Society of America, USA.

Zhao, X., Wang, S., Xu, L., \& Feng, Y. (2011) Practice and trend of DSAS in China. Proceeding in 2011 International Conference on Advanced Power System Automation and Protection, Beijing, 2011, pp. 17621766. doi: 10.1109/APAP.2011.6180836. 